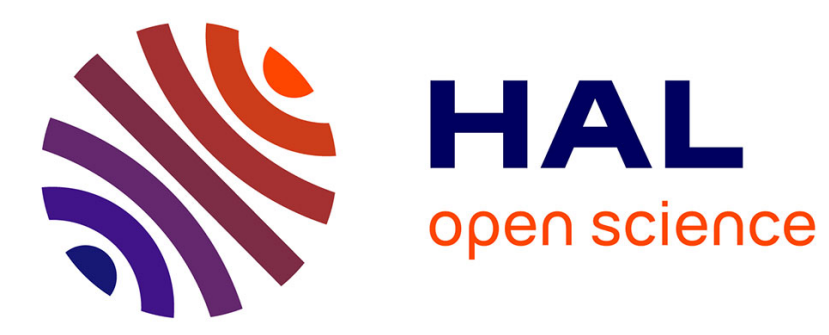

\title{
CELLULAR MECHANISMS INVOLVED IN CEREBELLAR MICROZONATION
}

Constantino Sotelo

\section{To cite this version:}

Constantino Sotelo. CELLULAR MECHANISMS INVOLVED IN CEREBELLAR MICROZONATION. Neuroscience, In press, 10.1016/j.neuroscience.2020.01.019 . hal-02985786

\section{HAL Id: hal-02985786 \\ https://hal.sorbonne-universite.fr/hal-02985786}

Submitted on 2 Nov 2020

HAL is a multi-disciplinary open access archive for the deposit and dissemination of scientific research documents, whether they are published or not. The documents may come from teaching and research institutions in France or abroad, or from public or private research centers.
L'archive ouverte pluridisciplinaire HAL, est destinée au dépôt et à la diffusion de documents scientifiques de niveau recherche, publiés ou non, émanant des établissements d'enseignement et de recherche français ou étrangers, des laboratoires publics ou privés. 


\section{CELLULAR MECHANISMS INVOLVED IN CEREBELLAR MICROZONATION}

\section{CONSTANTINO SOTELO1,2, *}

1. Sorbonne Universités, UPMC Université Paris 06, INSERM, CNRS, Institut de la Vision, 75012 Paris, France. (constantino.sotelo@inserm.fr).

2. Instituto de Neurociencias de Alicante, UMH-CSIC, Universidad Miguel Hernández de Elche, Alicante, Spain.

\section{List of abbreviations:}

It is with fare and admiration that I write this review in memory of one of the best, if not the best, expert of all those who have worked on cerebellum in recent History of Neurosciences, Professor Masao Ito. There is no doubt that with his death, the cerebellum and its followers, we are in mourning. He visited Paris several times, mainly between 1980 and 1984, when he was president of the IBRO (International Brain Organization). His visits gave me the opportunity to see him and discuss with him, wonderful moments that I will always remember.

\section{The cerebellum and motor coordination}

In spite of some curious and totally wrong ideas provided by Franz Joseph Gall (1809), who hypothesized that the cerebellum played an important role in sexual excitation, and was the center for sexual pleasure, the scientific history of the cerebellar functions starts with Luigi Rolando (1809) and Pierre Flourens (1824). The former hypothesized that the cerebellum was a kind of battery that produced the required electricity to generate muscle contraction, and therefore movement for locomotion. Conclusion severely criticized by Flourens who used his ablation and stimulation approaches to show that after the removal of the cerebellum the damaged animals were not paralyzed but they could no longer coordinate their movements. This concept, that the cerebellum was the coordinator of motor activity was 
corroborated and enlarged by Luigi Luciani (1891), and his observations on a dog that survived the ablation of the cerebellum, and developed a triad of symptoms (asthenia, atonia and astasia) that characterized cerebellar damage, and clearly points to the cerebellum as the coordinator of movement. Moreover, by its hodological organization the cerebellum is at the crossroads of the motor pathway. First, through the cortico-ponto-cerebellar projections it receives a copy of the motor commands descending from the motor cortex to the spinal cord, while it simultaneously receives feedback ascending sensory information from the spinal cord and brainstem. As a result the cerebellum is in a privileged position to coordinate of planned motor functions.

Today, despite the deep knowledge we have on the structure and cellular physiology of the cerebellum, the mechanisms by which it coordinates motility have been difficult to identify. Two almost contemporary models were published in the late 1960s to explain that the role of the cerebellum in motor coordination was based upon motor learning. For Marr (1969) the motor learning process took place because the synapses between parallel fibers and Purkinje cells (PCs) were facilitated by the coincidence of their activity with that of the climbing fibers. For Albus (1971), who accepted the hypothesis of this conjunction in the learning process, the mechanism was not via an increase but rather a diminution of parallel fiber excitability.

Masao Ito's main achievements in the study of the cerebellum have been numerous and important in revealing the mechanisms involved in motor coordination. Let me mention those that were the most stunning for me: First, the demonstration that inhibition was not restricted to interneurons, and that projection neurons could also be inhibitory, as in the case of PCs synapsing in the Deiters' nucleus (Ito and Yoshida, 1966), and that GABA was the neurotransmitter of this inhibition (Obata et al., 1967). The second and most important discovery was undoubtedly the one regarding the fact that a prolonged long-term-depression of the synapses (LTD) between parallel fibers and PCs, instead of a long-term potentiation, was the mechanism of synaptic plasticity necessary to regulate the motor learning of the 
cerebellum (Ito, 1982; Ito and Kano, 1982; Ito, 1989), giving its success to Albus' proposition.

Strong opposition to the cerebellum as a learning device came from supporters of the hypothesis that the olivocerebellar system is the organizer of the timing of movement, and the error corrector, as proposed by Rodolfo Llinás (1974; 2009). Although the holders of each hypothesis have the tendency to consider the other as misguided, After more of 40 years of fighting, finally Chris de Zeeuw and collaborators (Galliano and de Zeeuw, 2014) have reached a consensus that ends this long dispute: among the functions under cerebellar control, timing, motor error correction, as well as motor learning apply perfectly to the role exerted by the cerebellum in motor coordination. This conclusion gives reason to Masao Ito who has fought with determination to impose his results.

Last but nor least, the anatomical analysis of cerebellar projections using a transneuronal retrograde transport with neurotropic viruses as tracer, injected into physiological defined portions of primary motor cortex, showed that the second-order labeled neurons were located in deep cerebellar nuclei mainly the dentate nucleus (Middleton and Strick, 1994). This discovery opened a new chapter in cerebellar function by demonstrating that in addition of its role in motor coordination, the cerebellum has also a cognitive role (Schmahmann and Sherman, 1998) that is outside the focus of this review.

\section{CEREBELLAR PROJECTIONS MAPS IN ADULT CEREBELLUM}

The composition and organization of the neuronal circuitry in the cerebellar cortex remained 125 years later very similar to those revealed by Cajal (1894), except for the addition of a few more classes of interneurons, and the discovery a new projection pathways [I am referring to neuromodulatory systems, like the monoaminergic pathways (Hökfelt and Füxe, 1969)]. The circuit consists of one output neuron, the PCs, two main extracerebellar afferent systems, the climbing and the mossy fibers, and an interneuronal inhibitory network, composed by the molecular 
layer interneurons (basket and stellate cells), the under PC layer Lugaro cells, and the granular layer Golgi cells. The most important recent changes were: The discovery by Enrico Mugnaini and his collaborators of the unipolar brush cells (UBC), an excitatory class of granular layer interneurons that, opposite to the others cerebellar cell types, is not ubiquitously found all along the cortex, and are almost exclusively located in the vestibulocerebellum (Mugnaini and Floris, 1994). Moreover, this new class of glutamatergic interneuron is the source of intrinsic mossy fibers (Diño et al., 2000). Another surprising discovery was the presence in the cortical granular layer of mossy fibers originated from neurons of the cerebellar deep nuclei (Tolbert et al., 1976), that paradoxically most of them were GABAergic, that is to say inhibitory (Chan-Palay et al., 1979; Batini et al., 1989; Hámori and Takács, 1989).

Despite its apparent homogeneity, the cerebellum is not uniformly all along its two lateral hemispheres and central vermis. One of the first and decisive proofs against such evenness, in addition to the fact that not all cerebellar regions contain the same classes of neurons (see above for UBC), came from the study of the adult organization of its afferent and efferent projections. Jansen and Brodal (1940) were the first to reveal the columnar organization of the cortical outputs. Using the Marchi technique to follow postlesional PC axons by their myelin degeneration, these authors were able to establish that the corticonuclear projection was organized following "a definite topographical localization" with a clear mediolateral (sagittal) orientation. Regarding the inputs, first for the olivocerebellar projections (Voogd, 1967, for the anatomy and; Oscarsson1969 and 1973 for the electrophysiology), and later for spinal mossy fibers (Voogd, 1969) and pontocerebellar fibers (Serapide et al., 2001), it was shown that the cerebellum has a longitudinal organization determined by the successive apposition of structurally and functionally distinct longitudinal stripes. The specificity of each of these cerebellar compartments results from the precise pattern of its afferent and efferent connections, which constitute the cerebellar projection maps.

\section{HETEROGENEITY OF PURKINJE CELLS}

With the advent of histochemical techniques in the $20^{\text {th }}$ century, it became 
possible to determine the distribution patterns of specific molecules, such as 5'nucleotidase (Scott, 1963) and acetylcholinesterase (AChE) (Odutola, 1970, Marani and Voogd, 1977). These studies have shown that both molecules provided quite similar patterns. The chemical precipitate indicative of the enzymatic activity was located in the molecular layer of almost all lobules of the anterior and posterior lobes forming narrow sagittal bands alternating with zones only weakly stained. In neither case were PC somata visible: for 5'-nucleotidase the pattern reflects Bergmann fiber expression, and the AChE activity is located in or around the $\mathrm{PC}$ dendrites. It is important to mention, that the observed glial activity was induced by their associated PCs, because in mutant mice with almost complete PC death, as it is the case in purkinje cell degeneration mutants, the glial expression of 5'-nucleotidase activity has practically disappeared, and in nervous mutants it is preserved only in those bands in which PCs survived (Hess and Hess, 1986). Although the functional meaning of these biochemical differences remained unexplained, their location pattern was clearly correlated with the sagittal zonal principle that governs the projection maps of PC inputs and outputs.

The reality of the biochemical heterogeneity of the PCs was fully demonstrated with the work of Richard Hawkes and collaborators (see in Hawkes and Gravel, 1991, and Hawkes and Herrup, 1995). These investigators were able to obtain two monoclonal antibodies, the mab Q113 and the mab Q600, which selectively immunostained PCs, each one in a complete manner with soma, axon and dendrites including spines. Surprisingly the entire population of PCs was not stained, but only a subpopulation, both the same, although the mab Q113 was more useful because the hybridomas grew better, the supernatant worked at much higher dilutions $(1 / 1,000$ or more) and it Western blotted well (Hawkes et al., 1985). The pattern of distribution of Q113 positive and negative PCs, was easily to appraise on horizontal sections. It was composed by thin parasagittal zones containing positive PCs, alternating with thicker zones bearing unstained PCs. Two and five years later, the same group of investigators had already correlated the modular pattern of PC distribution with the known maps of extracerebellar projections of both climbing and mossy fibers (Gravel 
et al., 1987; 1990). Owing to the alternation of positive and negative stripes converting the cerebellar surface into the furrow of a zebra, the mab Q113 was coined with the name of zebrin II (Brochu et al., 1990). An important new step in this research has been the identification of the polypeptide that serves as antigen to the mab zebrin II. The screening of a mouse cerebellum cDNA expression library, allowed the isolation of cDNA clones of the $36 \times 10^{3} \mathrm{Mr}$ antigen, and the identification of the glycolytic isozyme aldolase C as zebrin II (Ahn et al., 1994). Beyond its housekeeping role in metabolism, the functional role of aldolase $\mathrm{C}$ in $\mathrm{PC}$ heterogeneity remains unknown. In any case, it has been established that many functional properties of PCs, such as simple spike firing rate, intrinsic excitability, complex spike rate, change from one module to another (Zhou et al., 2014). This cellular heterogeneity is not only a fact of the mouse cerebellum, but is phylogenetically preserved from fish to mammals (Brochu et al., 1990).

\section{DEVELOPMENT OF PURKINJE CELLS}

With the use of quail/chick chimeras it became possible to determine that the isthmic organizer regulating the differentiation of the cerebellum corresponds to the isthmic constriction marked by the interface of two neural tube territories expressing two different transcription factors, respectively OTX2 in the rostral and GBX2 in the caudal one (Hidalgo-Sanchez et al., 1999). Therefore, the expression of Fgf8 (Crossley et al. 1996) together with the Gbx2 induction and the concomitant repression of Otx2 are correlated with midbrain - hindbrain fate of caudal prosencephalon, giving origin to the perspective cerebellum (Joyner et al., 2000). Today is clearly established that the cerebellar neurons originate from two different regions of the proliferative neuroepitelium: the so-called primitive cerebellar neuroepithelium and the upper rhombic lip. The primitive cerebellar neuroepithelium is specialized in generating GABAergic inhibitory neurons under the influence of Ptfla transcription factor (Hoshino et al., 2005); in the mouse among these inhibitory neurons, PCs emerge earlier between E10.5-E13.5. Whereas, the upper rhombic lip 
generates excitatory glutamatergic neurons promoted by Atoh1 (also called Math1), even two weeks after birth (Ben Arie et al., 1997; Machold and Fishell, 2005).

The VZ subregion containing the precursors of PCs is also characterized by the strong expression of E-Cadherin, and a rather selective surface marker Neph3, which is a direct downstream target gene of Ptfla (Mizuhara et al., 2010). Moreover, Neurogenin1 and Neurogenin2, also downstream to Ptfla, are expressed in the VZ, and implicated in cell-cycle control and PC development (Zordan et al., 2008). Postmitotic PCs migrate dorsally to form the PC plate. It is during this stage that the first evidence of PC subtype specification is seen in Early B-cell factor2 (Ebf2) expression. Also outside the ventricular neuroepithelium, differentiating PCs express Lhx1/Lhx5 (Morales and Hatten, 2006) and Corl2 (Minaki et al. 2008), genes of great help for Keiko Muguruma et al. (2010) to asses if cells derived from stem cells have acquired the lineage of PCs.

\section{ACQUISITION OF PURKINJE CELL HETEROGENEITY}

Because there is a direct correlation between the date of birth of the PC and its location in the adult stripe (Hashimoto and Mikoshiba, 2003), both the PC subtype and the position information should be fated at a very early stage of development, just at the end of the proliferation of PC progenitors. However, as zebrin expression begins quite late (in mice after P5, Tano et al., 1992), researchers were trying to find temporal markers that would allow them to date such heterogeneity. The first indication of heterogeneity was detected with the study of Early B-cell factor 2' (Ebf2) expression (Chung et al., 2008) that was restricted to the late-born PC progenitor population fated to become the zebrin II/AldoC negative parasagittal stripes, and was already evident at E13.5. Therefore, it was corroborated that the fate of PCs takes place after the last mitosis of their progenitors, when young postmitotic PCs begin their dorsal migration from the primitive cerebellar neuroepithelium to their prospective cortical region to establish the cortical plate (Goffinet, 1983). 
Meanwhile, the late expression of zebrin was palliated by the fact that during the study of the embryonic cerebellum with some of the so-called Purkinje cell selective markers (those antibodies that only immunostaining this category of neurons in the cerebellum), there was a heterochronicity in PC expression. The first tested antigen, cGK (guanosine 3':5'-phosphate-dependent protein kinase) (Wassef and Sotelo, 1984), provided the first evidence of biochemical heterogeneity of developing Purkinje cells. Labeled cells started to express cGK by E17. At that age up till P3, the comparison of immunostained with adjacent, serially cut, Cresyl Violet stained sections showed that not all PCs were immunoreactive, and positive clusters alternated with negative ones without intermixing cells. In contrast, at later stages and in the adult, all Purkinje cells were immunoreactive. This conclusion was corroborated a year later (Wassef et al., 1985), using two other selective markers: antibodies against vitamin D-dependent calcium binding protein, $(\mathrm{CaBP})$, or against Purkinje cell-specific glycoprotein (PSG) that, like cGK, labeled all neurons of this category from a few days after birth and throughout adulthood. Each antibody gave a reproducible mosaic of positive and negative clusters in the perinatal cerebellum, thus demonstrating a transient biochemical compartmentalization of differentiating PCs.

\section{DEVELOPMENT AND REFINEMENT OF CLIMBING FIBER PROJECTIONS}

From E16 onward, antibodies against the calcium binding proteins, parvalbumin and calbindin, and the calcitonin gene related peptide stain partially overlapping territories of the inferior olive. This staining delimits, as above described for cerebellar PCs, a biochemical zonation of the inferior olive which is also combinatory and transient (Wassef et al., 1992a). In view of the fact that the biochemical parcellation of both the inferior olivary neurons and their cerebellar targets, the PCs, takes place at the same time (from E16, date on which the climbing fibers have not yet invaded the cerebellar parenchyma and contacted the PC clusters), it can be deduced that both processes occur simultaneously but independently of each 
other. Therefore, the transient biochemical individualization of subgroups of neurons during development could contribute to recognition mechanisms (see below).

Anatomical and physiological mapping disclosed that the ensemble of the inferior olivary axons, at the origin of all CFs, form a stereotyped array of stripes throughout the cerebellar cortex. There is a strict and reproducible topographical relationship between subnuclei of the inferior olivary complex and specific PC stripes and zones in the cerebellar cortex (Gravel et al. 1987). Jan Voogd and his colleagues (see references in Voogd and Ruigrok, 2004) have established a detailed mapping, culminating in a systematic comparison of inferior olive projections and zebrin II/ AldoC+/- stripes.

During development the axons of the contralateral inferior olivary neurons cross the midline ventrally, at the base of the brainstem, enter the cerebellar cortex via the inferior cerebellar peduncles (by E14/15 in mice - Paradies and Eisenman, 1993), and ramify amongst the PCs with CF subsets targeting specific PC clusters. In the rat, synaptic connections between CFs and PCs are present as early as E19 (1987; Wassef et al., 1992) but most synaptogenesis occurs postnatally. However, coarse olivocerebellar topography is established from the starting of the projection, and is roughly similar in newborn, 5-day-old, and adult rats (Sotelo et al., 1984). Cajal (1911) outlined three stages in the postnatal development of CF innervation, although a precocious stage takes place in perinatal rats $(\mathrm{P} 0)$, called the "creeper stage" (Chédotal and Sotelo, 1993), before the regression of the transient apical dendrite of developing PCs (Armengol and Sotelo, 1991) where this synaptogenesis started. CFs establish a few synaptic contacts, some of them of mature appearance, upon the smooth surface of the transient PC apical dendrites. The classical Cajal's (1911) stages are: the "pericellular nest" stage (P0-P5) that follows the "creeper stage", CFs from several olivary neurons form synaptic connections with PC somata. At the "capuchon" (hooded) stage $(\sim \mathrm{P} 8)$, also multiple CFs are first seen to accumulate at the apical pole of a PC soma, forming a kind of hood around the nascent ultimate stem dendrite "climbing" over the growing proximal dendrites. Finally, during the "young climbing fiber" stage (P9-15) the CF synapses translocate 
to contact the stubby thorns emerging from branches of the proximal dendritic compartment (reviewed in Sotelo and Chédotal, 2005; Watanabe and Kano, 2011).

The electrophysiological study carried out by Crepel (1971) indicates that synaptogenesis between CFs and Purkinje cells occurs postnatally in the rat, since the first functional identified synapses were observed in 3 day-old animals (P3). Although of longer duration, these $\mathrm{CF}$ responses are already very similar to adult ones. However, they are not all-or-none in nature, as in the adult cerebellum (Eccles et al., 1966), indicating the numerical matching of one CF per PC, but are graded in parallel with increasing intensity of stimulus. By P15, the responses acquire their all-or-none adult character, in favor of a transient multiple innervation (two up to five CFs per PC) (Crepel et al., 1976). The process of synapse elimination during the transition from multiple innervated PCs to single innervated PCs resembles the changes taking place during the development of neuromuscular junctions (Sanes and Lichtman, 1999). First a single dominant $\mathrm{CF}$ is selected, mediated by PC Ca2+ influx, resulting in one "strong" input and other "weaker" ones (Hashimoto and Kano, 2003).

Subsequently, mainly during P7-P14, the strong CF translocates from the soma to the dendritic arbor, "young climbing fiber" stage, and the weaker inputs are eliminated (Hashimoto et al., 2009a). The elimination of excess CFs is activitydependent: for example, altered neuronal activity either in the inferior olive (Andjus et al., 2003) or the PCs (Lorenzetto et al., 2009) both impede elimination and result in persistent multiple CF innervation. It is also proven that granule cell- $>\mathrm{PC}$ interactions play a role in CF elimination. For example, cerebella deficient in granule cells, as it is the case in the weaver mutant mouse, or in the central cerebellar mass of reeler mutation, in both instances, the absence of granular cells preserve CF multiinnervation in adulthood (e.g., Mariani et al., 1977). It is well documented that this regressive process involves glutamate receptors on PC dendritic spines since the elimination of glutamate receptor $\delta 2$ subunit (GluR $\delta 2)$, a receptor present in tertiary spines targets of parallel fibers, but absent from the stubby thorns contacted by CFs (Landsend et al., 1997), allows the single dominant CF to be selected normally but then the process stops (Hashimoto et al., 2009b). 


\section{Matching of positional information during the formation of cerebellar maps.}

Our 'matching hypothesis' is only a variant of the Sperry's (1963) chemoaffinity theory. All our observations suggest that the navigation of olivocerebellar axons is regulated by positional information shared between arrays of olivary neurons and their corresponding compartments of PCs. Therefore, the acquisition of subpopulation-type identities in inferior olivary neurons and their targets, the Purkinje cells, would allow the formation of the projection map by matching their shared positional cues (the 'matching hypothesis,' Sotelo and Wassef, 1991; Sotelo and Chédotal, 1997). Consistent with this proposal, in vitro studies demonstrated that experimental rotation of the cerebellar target before $\mathrm{CF}$ innervation produced a corresponding rotation of the $\mathrm{CF}$ projection, strongly suggesting that the alignment of PC stripes and CF terminal fields is achieved by direct chemospecific interactions (Chédotal et al., 1997). The molecules involved in the match between the precerebellar neurons and the Purkinje cells are still unknown. The first ones were adhesion molecules (BEN, cadherins), and more recently, Eph receptor tyrosine kinases and their ligands, the ephrins. The adhesion molecules might act as binding devices between the axonal growth cones and their postsynaptic partners. In contrast, Eph expressing growth cones would prevent neurons bearing the membrane bound corresponding ephrin, acting as repellent devices, as hypothesized in our in vitro experiments mentioned above.

\section{THE PROJECTION MAPS OF MOSSY FIBER AFFERENTS: DEVELOPMENT}

In opposition to what happens with climbing fibers that all of them are originated in the inferior olive (Desclin 1974), mossy fibers in the cerebellar cortex have multiple origins in the brainstem (trigeminal complex, vestibular nuclei and ganglion, nucleus prepositus hypoglosi, external cuneatus nucleus, and lateral reticular nucleus), and as reported above, from deep cerebellar nuclei. The less numerous mossy fibers arise from the trigeminal complex, deep cerebellar nuclei, 
vestibular nuclei and ganglion, nucleus prepositus hypoglosi, external cuneatus nucleus, and lateral reticular nucleus. While the most numerous and best known ones originate from the basilar pontine nuclei (including its nucleus reticularis tegmenti pontis) and the spinal cord. The last two origins (spinal cord and pontine nuclei) will be used here as example to summarize research done on the establishment of mossy fiber projection maps.

Spinal axons end almost exclusively in the vermis, where they are distributed within two distinct areas: the anterior target zone, which is the most important and comprises lobules I to $\mathrm{V}$ of the anterior lobe; and the posterior target zone, which is restricted to lobule VIII (Voogd, 1969). All spinal fibers terminate as mossy fibers in the granular layer, where they are segregated into five parallel sagittally situated zones varying in width from 200 to $480 \mu \mathrm{m}$ and separated by terminal-free intervals of 600 to $800 \mu \mathrm{m}$.

Anterograde tracer experiments carried out in rats aged $0,3,5,7$, and 30 days (Arsenio-Nunes and Sotelo, 1985) have permitted the conclusion that spinal axons reach the cerebellum during fetal life and that their ultimate organization is qualitatively attained by P7. Between P0 and P7 these axons must pass through the various developmental stages necessary for the establishment of the adult spinocerebellar topography. A summary of these successive stages follows.

1) The Early Stage of Axonal Growth: During intrauterine life, spinal axons grow rostrally in the ventrolateral aspect of the lower brain stem to the inferior and superior cerebellar peduncles. Once in the cerebellum, these fibers will end up directly at their adult locations, since transient aberrant projections were not detected. Thus, adult terminal domains correspond nicely with the "attracting" cerebellar zones for ingrowing spinal fibers.

2) The Intermediate Stage or Waiting Period: From P0 to P3 the ingrowing spinal axons remain in the prospective white matter, where they are distributed more or less 
uniformly. As in the case for olivocerebellar fibers, those emerging from spinal neurons also reach their appropriate territories before the proper maturation of their target cells, indicating that the latter are not involved in providing attractive guiding cues.

3) The Protocolumnar Stage: By P3 spinal axons begin to invade the cortical gray matter. Although Purkinje cells have not yet reached their final monolayer arrangement at this age, a nascent granular layer containing a noticeable contingent of granule cells already exists. The invasion by spinal fibers does not occur randomly, as they have a tendency to remain clustered within their ultimate terminal domains. However, some labeled fibers are still dispersed to an important degree between the nascent columns, hence the term protocolumnar stage.

4) The Columnar Stage: From P3, concomitant with the rapid increase in the amount of labeled spinal fibers entering the granular layer, intercolumnar dispersion diminishes. At P5 the columns have almost acquired their adult appearance, although a low degree of dispersion is still evident. From P7, adult topography is totally achieved; the five columns are situated as in P30 rat cerebellum. Besides changes in cerebellar size, the only difference in the adult is quantitative.

The ultrastructural examination of the immature lobules II and III of the anterior lobe of the vermis permits to disclose the synaptogenesis of mossy fiber maturation, mainly the spinocerebellar one. Using this approach, we have identified mossy fibers establishing synaptic contacts from P5 (Arsénio-Nunes and Sotelo, 1985). They appear as axonal varicosities partially covered by one or two postsynaptic dendrites and correspond to the primitive stage of mossy fiber synaptogenesis. By P7 the number of detectable mossy rosettes has increased and maturation has progressed. Here, mossy terminals in the primitive stage and in the cup stage (the most numerous) are intermixed with terminals already in the claw stage (see Larramendi, 1969 for the definition of these stages). Thus our results provide indirect evidence that spinocerebellar fibers may start synaptogenesis almost immediately after their 
invasion of the nascent granular layer, since by P5 primitive mossy rosettes bearing mature synaptic junctions are present in the terminal domains of spinal axons. The temporal correlation between the columnar organization of spinal axons and the appearance of mossy rosettes with mature synaptic junctions indicates that the process of synapse formation does not interfere with the organization of spinocerebellar topography.

The Purkinje cells as organizers of the mossy fiber projection maps. Study of the spinocerebellar projection in agranular cerebellum: weaver, staggerer and reeler mutant mice

How do mossy fibers to identify their terminal domains in a cerebellum in which their main postsynaptic partners, the dendrites of the granule cells, are still not developed? The analysis of the mossy fibers' development in mice suffering from spontaneous cerebellar mutations has greatly helped to understand this process. First, in granuloprival mutants where granule cells are directly (weaver) or indirectly (staggerer) the targets of the mutation, these relay cells are greatly rarify, and the cerebellum becomes almost agranular. In the weaver mouse $(w v / w v)$, the cellular target of the mutation are the granule cells that are affected by a missense mutation in a gene encoding a G-protein coupled inward rectifier potassium channel (GIRK2 $\mathrm{K}^{+}$ channel, Patil et al., 1995). These relay cells, although do proliferate, are unable to differentiate, and the majority of them die before migration (Sotelo and Changeux, 1974a). In the staggerer mouse ( $\mathrm{sg} / \mathrm{sg}$ ), the molecular target of the mutation is the retinoid-related orphan receptor $\alpha(R O R \alpha$, Hamilton et al. 1996; Steinmayr et al., 1998), a member of the nuclear receptor superfamily expressed in PCs. The absence of $R O R \alpha$ abolishes the development of cerebellar PCs in a cell-autonomous fashion, resulting in an important decrease of their number, with altered function and lack of spines in the distal PC dendritic branches in the remaining ones (Sidman et al. 1962; Sotelo and Changeux, 1974b). The conjoint lack of suggesting the essential role of ROR $\alpha$ in the terminal differentiation of PCs. Knowing the role of PCs as sonic hedgehog $(S h h)$ producers, and the need of parallel fibers of their main postsynaptic targets for their maintenance, and the importance of this mitogen for the proliferation 
of granule cells (Wechsler-Reya etal., 1999), as expected the staggerer cerebellum is almost agranular. Nevertheless, despite their scantiness, the remaining granule cells are unaffected.

The organization of the spinocerebellar projection was analyzed by the anterograde axonal WGA-HRP (wheat germ agglutinin conjugate - horseradish peroxidase) tracing method in the granuloprival cerebellar cortex of these two mutant mice (Arsenio-Nunes et al., 1988). In the weaver mouse, despite the rarity of granule cells, and that they are directly affected by the mutated gene, the spinal axons reproduce the normal spinocerebellar pattern with few differences. Conversely, in staggerer mouse, in which the PCs are intrinsically affected but granule neurons do not seem perturbed by the staggerer gene action, the spinocerebellar organization is severely altered. Indeed, they do not organize in terminal modules arranged parasagittally, but they distribute more or less homogeneously in the lobes of the vermis, where they spread evenly within the cortex.

The important conclusion that can be drawn from the study of the development of spinocerebellar projections in the wild and mutant mice is that granule cells, the synaptic targets of mossy fibers are neither necessary to attract the fibers to their proper terminal domains nor for their parasagittal organization. Purkinje cells, on the contrary, are required for the proper location of these fibers, and appear again as the organizers of the cerebellar projection maps. How do play Purkinje cells its organizer role? A tentative explanation could be drawn from the following two facts:

i) It has been shown that in granuloprival cerebella, a condition in which the main post-synaptic target for parallel fibers, the Purkinje cell, remains in a synaptic "non-saturated" state because under normal conditions at least 95\% of its synaptic inputs are provided by granule cells, heterologous synapses have been constantly found. Therefore, either in mutant mice (weaver and reeler) or in teratologic granuloprival states, obtained either by postnatal X-irradiation or infection with feline panleukopenia virus, mossy fibers were able to establish morphological and functional synapses on Purkinje cell spines (Llinás et al., 1973; Sotelo, 1973, 1975; Mariani et al., 1977; Wilson et al., 1981). In the contest of the chemoaffinity 
hypothesis of Roger Sperry (1963), the formation of heterologous synapses appears to be consistent with a mechanism which recognizes a wide range of graded preferences between synaptic partners rather than an exclusive or even a narrow range of synaptic affinities. Thus, under conditions of "non - saturation" by the favored axonal class, in our case the parallel fibers, the Purkinje cell appears able to accept as a stable synaptic target, other axons systems with a decreasing order of priority. After parallel fibers, the first next priority system appears to be the spinocerebellar mossy fibers.

ii) More important, past studies of the development of mossy fibers in postnatal mouse cerebellum have revealed the existence of mossy fiber - Purkinje cell synapses (Mason and Gregory, 1984; Mason, 1985). These synapses are only transient and might act as "guidepost cells" to guide the arriving mossy fibers to the developing cerebellar cortex, keeping them in proper location during their waiting for the proliferation, migration and differentiation of granule cells, the relay cells in the mossy fiber transfer of information to Purkinje cell in mature cerebellar circuit. The neurons of origin of the mossy fibers transiently synapsing on Purkinje cells was not determined in this study, since the tracer filling of the fibers was done on slices of cerebellum. Later on, the existence of these transient synapses was corroborated using electrophysiological methods combined with ultrastructural studies (Takeda and Maekawa, 1989). At birth, simple spikes responses with a short latency were recorded in the vestibulocerebellum after stimulation of the vestibular nerve, and mossy fibers labeled with HRP showed fine branching at the level of Purkinje cell somata. Some of the thin processes emerging from the branching were filled with synaptic vesicles and in apposition with the latter. These direct connections were found during days P7-P20. The conjunction of these two facts strongly suggests that Purkinje cells are the sole organizers of the projection maps of the cerebellar cortex, as we proposed years ago (Sotelo and Wassef, 1991; Sotelo and Chédotal, 1997).

In conclusion, cerebellar maps are organized by matching topographic chemical labels between incoming afferent fibers and Purkinje cells. This mechanism appears to be able to construct maps to the level of small modular cerebellar zones. It is possible that the fine-tuning of the projection to the single cell level still requires an 
additional mechanism based upon activity of the developing circuitry, implying the redundancy of the forming climbing fibers synapses, and the regression of supernumerary ones, as postulated by Changeux and Danchin (1976) in their theory of selective stabilization of synapses.

\section{REFERENCES LIST}

Ahn AH, Dziennis S, Hawkes R, Herrup K. (1994) The cloning of zebrin II reveals its identity with aldolase C. Development 120: 2081-2090.

Albus JA. (1971) A theory of cerebellar function. Mathematical Biosciences 10: 25-61.

Andjus PR, Zhu L, Cesa R, Carulli D, Strata P. (2003) A change in the pattern of activity affects the developmental regression of the Purkinje cell polyinnervation by climbing fibers in the rat cerebellum. Neuroscience. 121(3), 563-72.

Armengol JA, Sotelo C. (1991) Early dendritic development of Purkinje cells in the rat cerebellum. A light and electron microscopic study using axonal tracing in 'in vitro' slices. Dev. Brain Res. 64: 95-114.

Armstrong C.L., Hawkes, R. (2014) "Pattern Formation in the Cerebellum". Colloquium Digital Library of Life Sciences. Morgan \& Claypool, pp. 1-137.

Arsenio-Nunes, M.L., Sotelo, C. (1985) Development of the spinocerebellar system in the postnatal rat. J. Comp.Neurol. 237: 291-306.

Arsenio-Nunes, M.L., Sotelo, C., Werhrlé R. (1988). Organization of spinocerebellar projection map in three types of agranular cerebellum: Purkinje cells vs. Granule cells as organizer element. J. Comp. Neurol. 273: 120-136.

Batini, C., Buisseret-Delmas, C., Compoint, C. Daniel, H. (1989) The GABAergic neurons of the cerebellar nuclei in the rat: projections to the cerebellar cortex. Neurosci. Let. 99: 251-256.

Batini, C., Compoint, C., Buissere-Delmas, C., Daniel, H., Guegan, M. (1992) Cerebellar nuclei and the nucleocortical projection in the rat: retrograde tracing coupled to GABA and glutamate immunohistochemistry. J. Comp. Neurol. 315: 74-84.

Ben-Arie, N., Bellen, H.J., Armstrong, D.L., McCall, A.E., Gordadze, P.R., Guo, Q., Matzuk, M.M., Zoghbi, H.Y. (1997) Math1 is essential for genesis of cerebellar granule neurons. Nature 390: 169-172

Brochu, G., Maler, L., Hawkes, R., (1990) Zebrin II: a polypeptide antigen expressed 
selectively by Purkinje cells reveals compartments in rat and fish cerebellum. J. Comp.Neurol. 291: 538-552.

Cajal, S.R. (1894) The Croonian Lecture: La fine structure des centres nerveux. Proc. R. Soc. Lond. 55: 444-468.

Cajal, S.R. 1911. Histologie du Système Nerveux de l'Homme et des Vertébrés. Volume 2. Paris, Maloine.

Chan-Palay, V, Palay, S L and Wu, J -Y, (1979) Gamma-ammobutyric acid pathways in the cerebellum studied by retrograde and anterograde transports of glutamic acid decarboxylase antibody after in vivo injections, Anat Embryol, 157: 1-14.

Changeux JP, Danchin A. (1976) Selective stabilisation of developing synapses as a mechanism for the specification of neuronal networks. Nature 264(5588): 705-712.

Chédotal, A., Sotelo, C. 1993. The "creeper stage" in cerebellar climbing fiber synaptogenesis precedes the "pericellular nest": ultrastructural evidence with parvalbumin immunocytochemistry. Dev. Brain Res. 76: 207-220.

Chédotal, A., Bloch-Gallego, E., Sotelo, C. (1997) The embryonic cerebellum contains topographic cues that guide developing inferior olivary axons. Development 124: 861-870.

Chung SH, Marzban H, Croci L, Consalez GG, Hawkes R. 2008. Purkinje cell subtype specification in the cerebellar cortex: early B-cell factor 2 acts to repress the zebrin II-positive Purkinje cell phenotype. Neuroscience. 153(3), 721-732.

Crepel F, Mariani J, Delhaye-Bouchaud N. (1976) Evidence for a multiple innervation of Purkinje cells by climbing fibers in the immature rat cerebellum. J. Neurobiol. 7: 567-578.

Desclin, J.C. (1974). Histological evidence supporting the inferior olive as the major source of cerebellar climbing fibers in the rat. Brain Res. 77: 365-384.

Diño, M.R., Schuerger, R.J., Liu, Y.-B., Slater, N.T., Mugnaini, E. (2000) Unipolar brush cell: a potential feedforward excitatory interneuron in the cerebellum. Neuroscience 98: 625-636.

Eccles, J.C., Llinás, R, Sasaki, K. (1966) The excitatory synaptic action of climbing fibers on the Purkinje cells of the cerebellum, J. Physiol. (Lond.), 182 (1966) 268 $-296$.

Flourens, P. (1824) Recherches expérimentales sur les propriétés et les fonctions du système nerveux, dans les animaux vertébrés. Imprimerie de la Chevardiere Fils. pp. 331.

Gall, FJ. (1809) Untersuchungen über die Anatomie des Nervensystems überhaupt, und des Gehirns insbesondere, ein dem französischen Institute überreichtes Memoire von Gall und Spurzheim... Édition : Paris und Strassburg, pp.468. 
Galliano, E., De Zeeuw, C.I. (2014) Questioning the cerebellar doctrine. Prog. Brain Res. 210: 59-77.

Goffinet, AM. (1983) The embryonic development of the cerebellum in normal and reeler mutant mice. Anat. Embryiol. 168: 73-86.

Gould BB, Graybiel AM (1976) Afferents to the cerebellar cortex in the cat: evidence for an intrinsic pathway leading from the deep nuclei to the cortex. Brain Res. 110: 601-611.

Gravel, C., Eisenman, LM., Sasseville, R., Hawkes, R. (1987) Parasagittal organization of the rat cerebellar cortex: direct correlation between antigenic Purkinje cell bands revealed by mab Q113 and the organization of the olivocerebellar projection. J. Comp. Neurol. 265: 294-310.

Gravel, C., Hawkes, R. (1990) Parasagittal organization of the rat cerebellar cortex: direct comparison of Purkinje cell compartments and the organization of spinocerebellar projection. J. Comp. Neurol. 291: 79-102.

Hamilton BA, Frankel WN, Kerrebrock AW, Hawkins TL, FitzHugh W, Kusumi K, Russell LB, Mueller KL, van Berkel V, Birren BW, Kruglyak L, Lander ES. (1996) Disruption of the nuclear hormone receptor RORalpha in staggerer mice. Nature. 379: 736-739.

Hámori J, Takács J. (1989) Two types of GABA-containing axon terminals in cerebellar glomeruli of the cat: an imminogold-EM study. Exp. Brain Res.74(3): 471-479.

Hashimoto, K., Kano, M. 2003. Functional differentiation of multiple climbing fiber inputs during synapse elimination in the developing cerebellum. Neuron 38: 785-796.

Hashimoto K, Ichikawa R, Kitamura K, Watanabe M, Kano M. (2009a) Translocation of a "winner" climbing fiber to the Purkinje cell dendrite and subsequent elimination of "losers" from the soma in developing cerebellum. Neuron. 63: 106-118.

Hashimoto K, Yoshida T, Sakimura K, Mishina M, Watanabe M, Kano M. (2009b) Influence of parallel fiber-Purkinje cell synapse formation on postnatal development of climbing fiber-Purkinje cell synapses in the cerebellum. Neuroscience 162: 601-611.

Hashimoto, M., Mikoshiba, K. (2003) Mediolateral compartmentalization of the cerebellum is determined on the "birthdate" of Purkinje cells. J. Neurosci. 23: 11342-11351.

Hawkes, R., Gravel, C. (1991) The modular cerebellum. Prog. Neurobiol. 36: 309-327.

Hawkes, R., Herrup, K. (1995) Aldolase C/zebrin II and the regionalization of the cerebellum. J. Mol. Neurosci. 6: 147-158. 
Hawkes, R., Colonnier, M., Leclerc N. (1985) Monoclonal antibodies reveal sagittal banding in the rodent cerebellar cortex. Brain Res. 333: 359-365.

Hess, DT., Hess, A. (1986) 5'-Nucleotidase of cerebellar molecular layer: reduction in Purkinje cell-deficient mutant mice. Brain Res. 394: 93-100.

Hidalgo-Sánchez, M., Simeone, A., Alvarado-Mallart, RM. (1999) Fgf8 and Gbx2 induction concomitant with Otx2 repression is correlated with midbrain-hindbrain fate of caudal prosencephalon. Development 126: 3191-3203.

Hökfelt T, Fuxe K. (1969) Cerebellar monoamine nerve terminals, a new type of afferent fibers to the cortex cerebelli. Exp. Brain Res. 9: 63-72.

Hoshino M, Nakamura S, Mori K, Kawauchi T, Terao M, Nishimura YV, Fukuda A, Fuse T, Matsuo N, Sone M, Watanabe M, Bito H, Terashima T, Wright CV, Kawaguchi Y, Nakao K, Nabeshima Y (2005) Ptfla, a bHLH transcriptional gene, defines GABAergic neuronal fates in cerebellum. Neuron 47:201-213

Ito, M. (1982) Experimental verification of Marr-Albus' plasticity assumption for the cerebellum. Acta Biol. Acad. Sci. Hung. 33: 189-199.

Ito, M. (1989) Long-term depression. Annu. Rev. Neurosci. 12: 85-102.

Ito, M., Kano, M. (1982) Long-lasting depression of parallel fiber - Purkinje cell transmission induced by conjunctive stimulation of parallel fibers and climbing fibers in the cerebellar cortex. Neurosci. Let. 33: 253-258.

Ito, M., Yoshida, M. (1966) The origin of cerebral-induced inhibition of Deiters neurons. I. Monosynaptic initiation of inhibitory postsynaptic potentials. Exp. Brain Res. 2: 330-349.

Jansen, J., Brodal, A. (1940) Experimental studies on the intrinsic fibers of the cerebellum. II. The cortico-nuclear projection. J. Comp. Neurol. 73: 267-321.

Joyner, A.L., Liu, A., Millet, S. (2000) Otx2, Gbx2 and Fgf8 interact to position and maintain a mid-hindbrain organizer. Curr. Opin. Cell Biol. 12: 736-741.

Landsend, AS., Amiry-Moghaddam, M; Matsubara, A., Bergersen, L., Usami, S., Wenthold, R.J., Ottersen, OP. (1997) Differential localization of delta glutamate receptors in the rat cerebellum: coexpression with AMPA receptors in parallel fiberspine synapses and absence from climbing fiber-spine synapses.J Neurosci. 17: 834-842.

Larramendi, L.M.H. (1969): Analysis of the synaptogenesis in the cerebellum of the mouse. In: "Neurobiology of Cerebellar Evolution and Development" (R. Llinás, ed.). Chicago: American Medical Association, pp. 803-843.

Llinás R. (1974) Eighteenth Bowditch lecture. Motor aspects of cerebellar control. Physiologist. 17:19-46. 
Llinás R. R. (2009) Inferior olive oscillations as a temporal basis for motricity and oscillatory reset as the basis for motor error correction. Neuroscience 162: 797-804.

Llinás R., Hillman, DE., Precht, W. (1973) Neuronal circuit reorganization in mammalian agranular cerebellar cortex. J. Neurobiol. 4: 69-94.

Lorenzetto E, Caselli L, Feng G, Yuan W, Nerbonne JM, Sanes JR, Buffelli M. 2009. Genetic perturbation of postsynaptic activity regulates synapse elimination in developing cerebellum. Proc. Natl. Acad. Sci. USA 106: 16475-16480.

Luciani, L. (1891) Il cervelletto: Nuovi studi di fisiologia normale e patologica. Firenze, Italy, Le Monnier.

Machold, R., Fishell, G. (2005) Math1 is expressed in temporally discrete pools of cerebellar rhombic-lip neural progenitors. Neuron 48: 17-24.

Marani, E., Voogd, J. (1977) An acetylcholinesterase band-pattern in the molecular layer of the cat cerebellum. J. Anat. 124: 335-345.

Mariani, J., Crepel F, Mikoshiba K, Changeux JP, Sotelo C. (1977) Anatomical, physiological and biochemical studies of the cerebellum from reeler mutant mouse. Phil. Trans. Royal Soc. Lond. B. Biol Sci. 281: 1-28.

Marr, D. (1969) A theory of cerebellar cortex. J.Physiol. 202: 437-470.

Mason, CA., (1985) Growing tips of embryonic cerebellar axons in vivo. J. Neurosci. Res. 13: 55-73.

Mason, C.A., Gregory, E. (1984) Postnatal maturation of cerebellar mossy and climbing fibers: transient expression of dual features on single axons. J. Neurosci. 4: 1715-1735.

Middleton FA, Strick PL. (1994) Anatomical evidence for cerebellar and basal ganglia involvement in higher cognitive function. Science 266:458-461.

Minaki, Y., Nakatani, T., Mizuhara, E., Inoue, T., Ono, Y. (2008) Identification of a novel transcriptional co-repressor, Corl2, as a cerebellar Purkinje cell-selective marker. Gene Expr. Patterns 8: 418-423.

Mizuhara E, Minaki Y, Nakatani T, Kumai M, Inoue T, Muguruma K, Sasai Y, Ono Y. (2010) Purkinje cells originate from cerebellar ventricular zone progenitors positive for Neph3 and E-cadherin. Dev. Biol. 338: 202-214.

Morales, D., Hatten, M.E. (2006) Molecular markers of neuronal progenitors in the embryonic cerebellar anlage.J. Neurosci. 26: 12226-12236.

Mugnaini, E., Floris, A. (1994) The unipolar brush cell: a neglected neuron of the mammalian cerebellar cortex. J. Comp. Neurol. 339: 174-180.

Muguruma K, Nishiyama A, Ono Y, Miyawaki H, Mizuhara E, Hori S, Kakizuka A, Obata K, Yanagawa Y, Hirano T, Sasai Y.(2010) Ontogeny-recapitulating generation and tissue integration of ES cell-derived Purkinje cells. Nat. Neurosci. 13:1171-1180. 
Obata, K., Ito, M., Ochi, R., Sato, N. (1967) Pharmacological properties of the postsynaptic inhibition by Purkinje cell axons and the action of gamma-aminobutyric acid on Deiters neurons. Exp. Brain Res. 4: 43-57.

Odutola, AB. (1970) The topographical localization of acetylcholinesterase in the adult rat cerebellum: a reappraisal. Histochimie 23 : 98-106.

Oscarsson, O. (1969) Termination and functional organization of the dorsal spinoolivocerebellar path. J. Physiol. 200: 129-149.

Oscarson, 0. (1973) Functional organization of spinocerebellar paths. In A. Iggo (ed): Somatosensory System. Handbook of Sensory Physiology. Heidelberg: Springer, pp. 339-380.

Paradies, MA., Eisenman, LM. (1993) Evidence of early topographic organization in the embryonic olivocerebellar projection: a model system for the study of pattern formation processes in the central nervous system. Dev. Dyn. 197 : 125-145.

Patil, N., Cox, D.R., Bhat, D., Faham, M., Myers, R.M., Peterson, A.S. (1995) A potassium channel mutation in weaver mice implicates membrane excitability in granule cell differentiation. Nat. Genet. 11:126-129.

Rolando, L. (1809) Saggio sopra la vera struttura del cervello dell' uomo e degl' animali et sopra le funzioni del sistema nervoso. Sassari, Nella Stamperia da S.S.R.M. Privilegiata.

Sanes, JR., Lichtman JW. (1999) Development of the vertebrate neuromuscular junction. Annu. Rev. Neurosci. 22: 389-442.

Schmahmann, J.D., Sherman, J.C. (1998) The cerebellar cognitive affective syndrome. Brain 121:561-579.

Scott; TG. (1963) A unique pattern of localization within the cerebellum. Nature 200: 793.

Serapide, MF., Panto, MR., Parenti, R., Zappala, A., Cicirata, FF. (2001) Multiple zonal projections of the basilar pontine nuclei to the cerebellar cortex of the rat. J. Comp. Neurol. 430: 471-484

Sidman, RL., Lane, PW., Dickie, MM. (1962) Staggerer, a new mutation in the mouse affecting the cerebellum. Science 137: 610-612.

Sotelo, C. (1973) Permanence and fate of paramembranous synaptic specializations in "mutants" and experimental animals. Brain Res. 62: 345-351.

Sotelo, C; (1975) Anatomical, physiological and biochemical studies of the cerebellum from mutant mice. II. Morphological study of cerebellar cortical neurons and circuits in the weaver mouse. Brain Res. 94:19-44. 
Sotelo, C. (2004) Cellular and genetic regulation of the development of the cerebellar system. Prog. Neurobiol. 72: 295-339.

Sotelo C, Bourrat F, Triller A. (1984) Postnatal development of the inferior olivary complex in the rat. II. Topographic organization of the immature olivocerebellar projection. J. Comp. Neurol. 222: 177-199.

Sotelo, C., Changeux, JP. (1974a) Transsynaptic degeneration « en cascade » in the cerebellar cortex of staggerer mutant mice. Brain Res. 67: 519-526.

Sotelo, C., Changeux, JP. (1974b) Bergmann fibers and granular cell migration in the cerebellum of homozygous weaver mutant mouse. Brain Res. 77: 484-491.

Sotelo, C. Chédotal, A. (1997) Development of the olivocerebellar projection. Perspectives on Developmental Neurobiology. 5: 57-67.

Sotelo, C., Chédotal, A. (2005) Development of the olivocerebellar system: migration and formation of cerebellar maps. Prog. Brain Res. 148: 3-20.

Sotelo, C., Wassef, M. (1991) Cerebellar development: afferent organization and Purkinje cell heterogeneity. Phil. Trans. R. S. Lond. B. 331: 307-313.

Sperry, R.W. (1963) Chemoaffinity in the orderly growth of nerve fiber patterns and connections. Proc.Natl. Acad. Sci. USA. 50: 703-710.

Steinmayr, M., André, E., Conquet, F., Rondi-Reig, L., Delhaye-Bouchaud, N., Auclair, N., Daniel, H., Crépel, F., Mariani, J., Sotelo, C., Becker-André, M. (1998) Staggerer phenotype in retinoid-related orphan receptor $\alpha$-deficient mice. Proc. Natl. Acad. Sci. USA 95: 3960-3965.

Takeda T, Maekawa K. (1989) Transient direct connexion of vestibular mossy fibers to the vestibulocerebellar Purkinje cells in early postnatal developmen of kittens.

Neuroscience 32: 99-111.

Tano, D., Napieralski, JA., Eisenman, LM., Messer, A. Plummer, J., Hawkes, R. (1992) Novel developmental boundary in the cerebellum revealed by zebrin expression in the lurcher (Lc/+) mutant mouse. J. Comp. Neurol. 323: 128-136.

Tolbert DL, Bantli H, Bloedel JR (1976) Anatomical and physiological evidence for a cerebellar nucleocortical projection in the cat. Neuroscience 1: 205-217.

Voogd, J. (1967) Comparative aspects of the structure and fibre connexions of the mammalian cerebellum. Prog. Brain Res. 26: 94-134.

Voogd, J. (1969) The importance of fiber connections in the comparative anatomy of the mammalian cerebellum. In R. Llinas (ed): Neurobiology of Cerebellar Evolution and Development. Chicago: A.M.A.E.R.F. Institute for Biomedical Research, pp. 493-514.

Voogd,J., Ruigrok, TJ. (2004) The organization of corticonuclear and olivocerebellar climbing fiber projections to the rat cerebellar vermis: the congruence of projection zones and the zebrin pattern. J. Neurocytol. 33: 5-21. 
Wassef, M., Sotelo, C. (1984). Asynchrony in the expression of guanosine 3':5'phosphate dependent protein kinase by clusters of Purkinje cells during the perinatal development of rat cerebellum. Neuroscience 13: 1217-1241.

Wassef, M., Zanetta, JP., Brehier, A., Sotelo, C. (1985). Transient biochemical compartmentalization of Purkinje cells during early cerebellar development. Dev. BioL 111,129-137.

Wassef M, Chedotal A, Cholley B, Thomasset M, Heizmann CW, Sotelo C. (1992a) Development of the olivocerebellar projection in the rat: I. Transient biochemical compartmentation of the inferior olive. J Comp. Neurol. 323: 519-536.

Wassef, M., Cholley, B., Heizmann, CW., Sotelo, C. (1992b) Development of the olivocerebellar projection in the rat: II. Matching of the developmental compartmentations of the cerebellum and inferior olive through the projection map. J. Comp. Neurol. 323: 537-550.

Watanabe, M., Kano M. (2011) Climbing fiber synapse elimination in cerebellar Purkinje cells. Eur. J. Neurosci. 34: 1697-1710

Wechsler-Reya, R.J., Scott, M.P. (1999) Control of neuronal precursor proliferation in the cerebellum by Sonic Hedgehog. Neuron 22, 103-114

Wilson, L., Sotelo, C., Caviness,VS. (1981) Heterologous synapses upon Purkinje cells in the cerebellum of the reeler mutant mouse. An experimental light and electron microscopic study. Brain Res. 213:63-82.

Zhou H, Lin Z, Voges K, Ju C, Gao Z, Bosman LW, Ruigrok TJ, Hoebeek FE, De Zeeuw CI, Schonewille M. (2014) Cerebellar modules operate at different frequencies. Elife. 3: e02536. doi: 10.7554/eLife.02536.

Zordan, P., Croci, L., Hawkes, R., Consalez, G.G. (2008) Comparative analysis of proneural gene expression in the embryonic cerebellum. Dev. Dyn. 237:1726-1735. 
FIGURE 1 

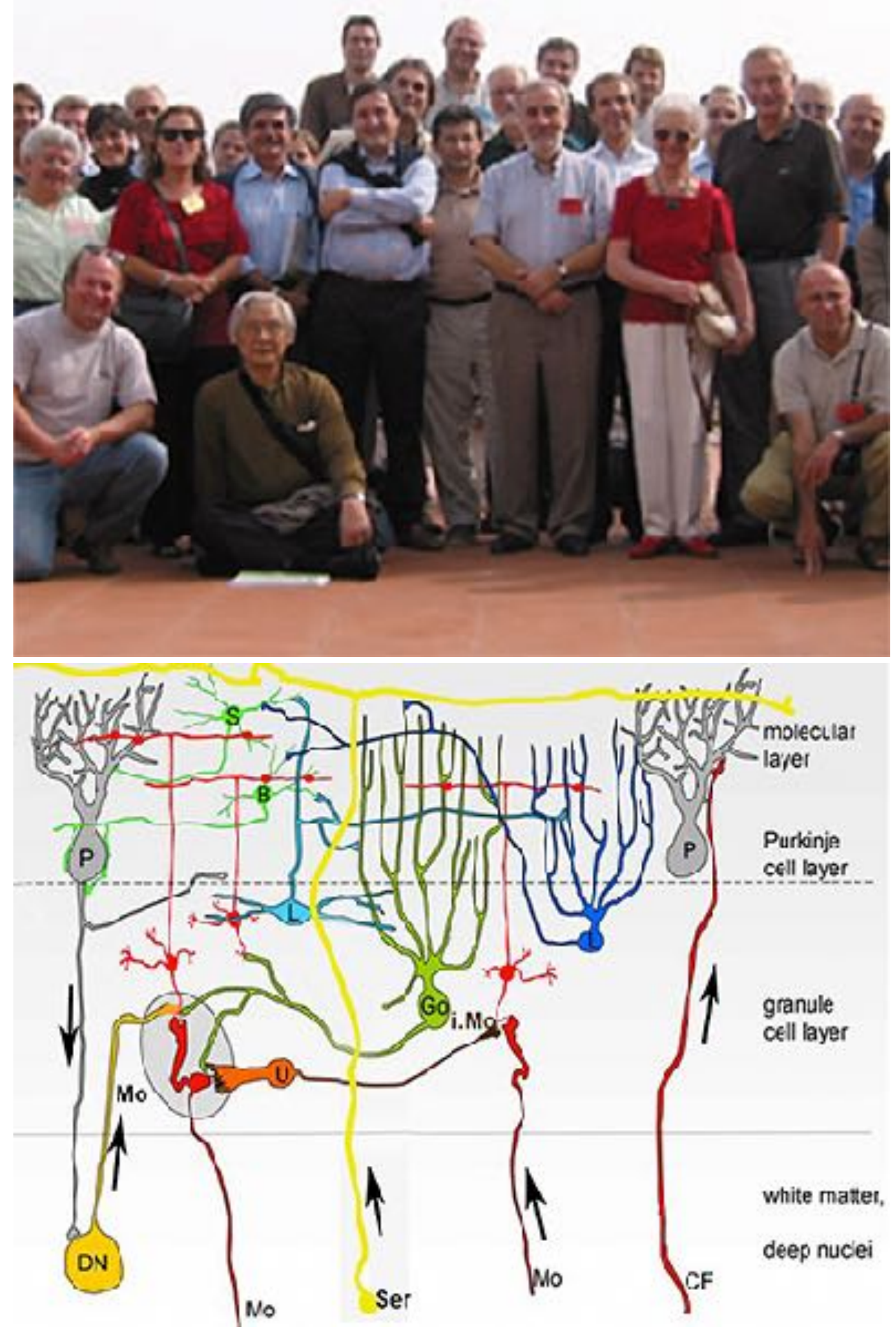

FIGURE 2

FIGURE 3 

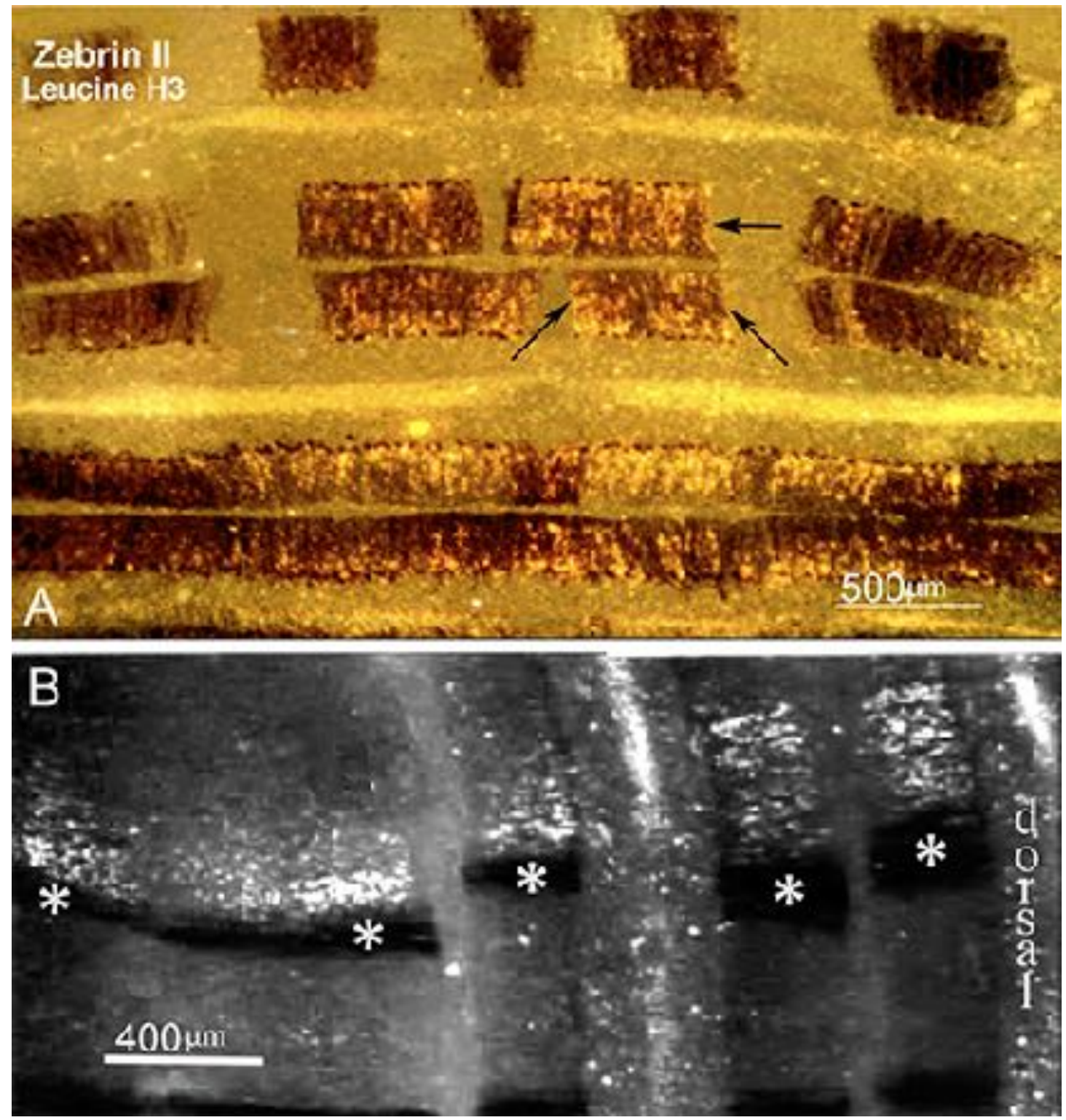
FIGURE 4
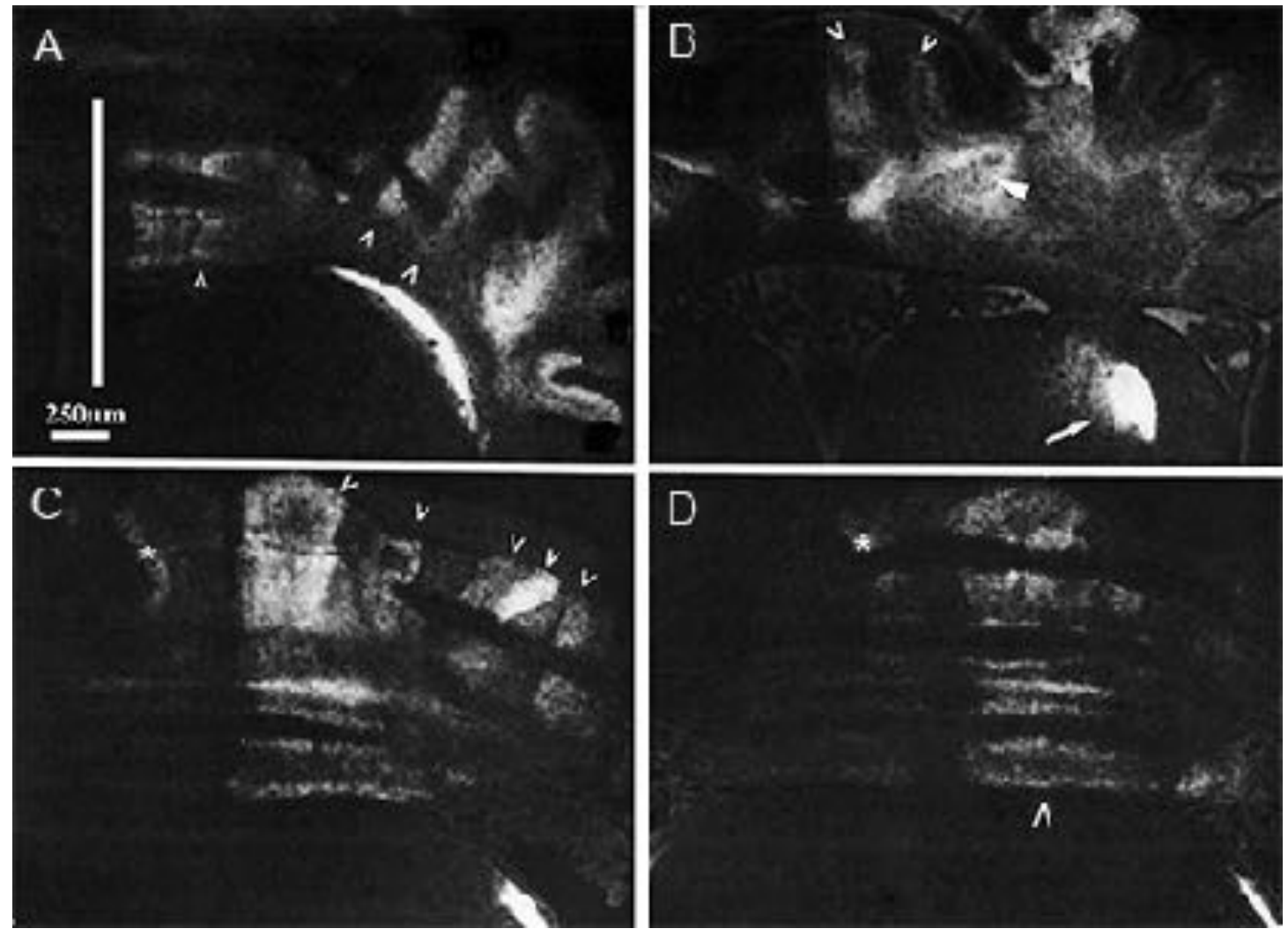

FIGURE 5
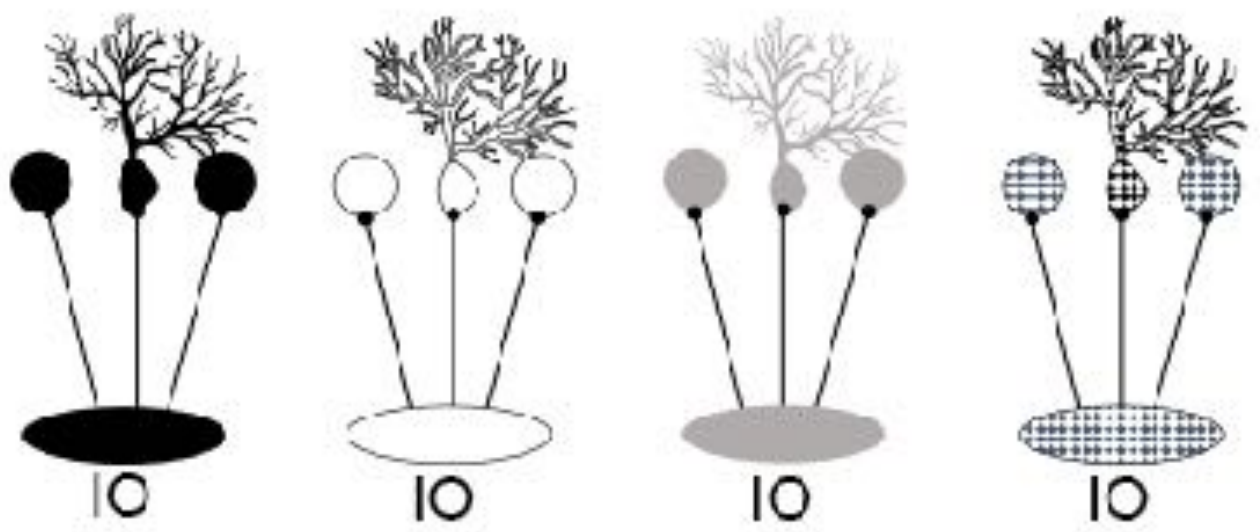
FIGURE 6

A

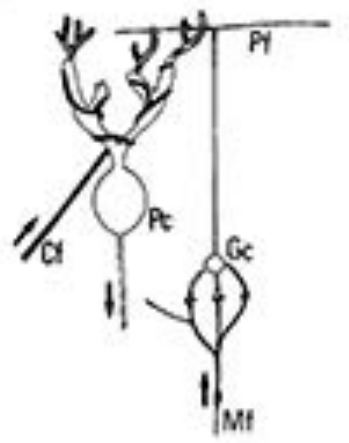

a *
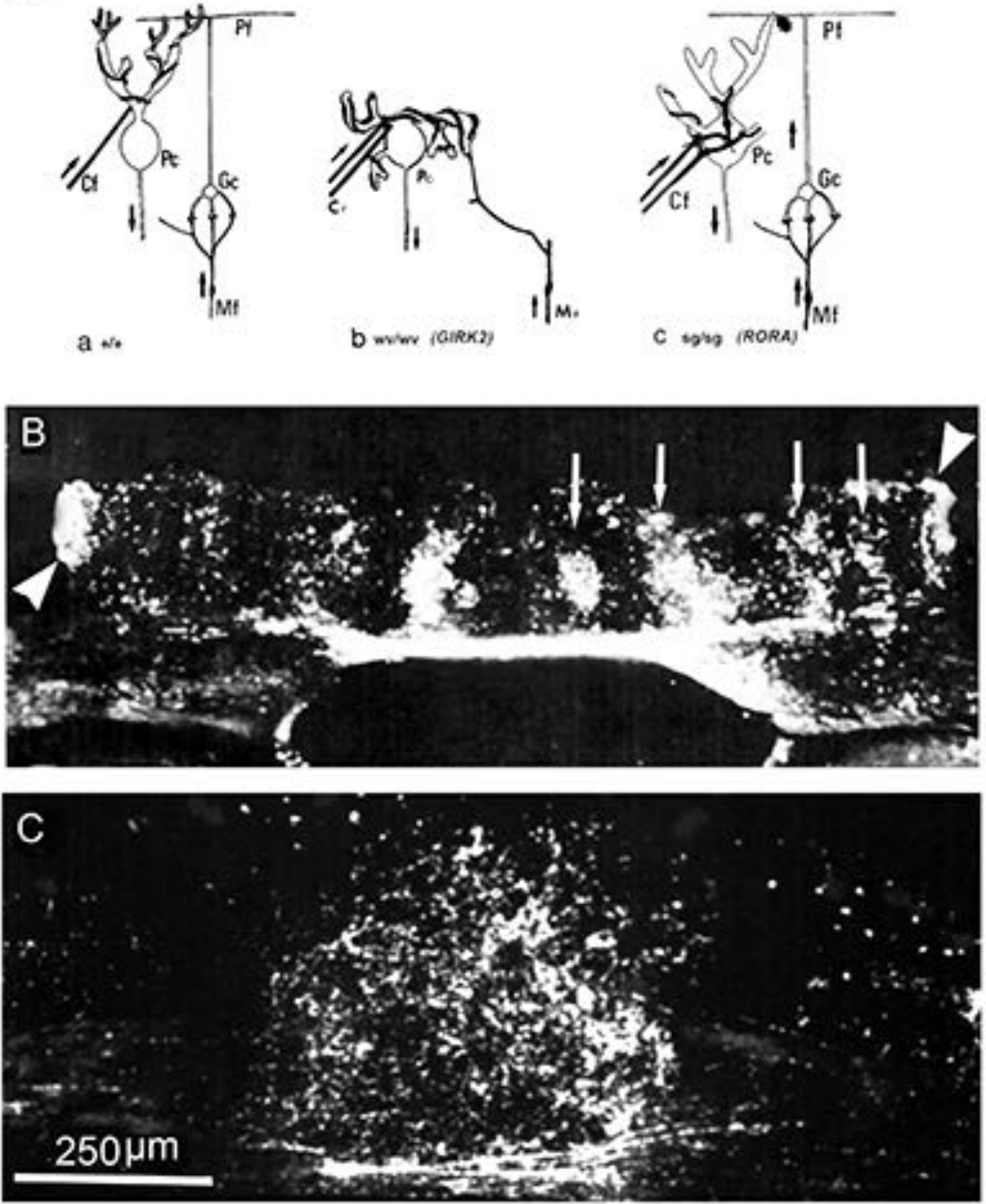
FIGURE 7

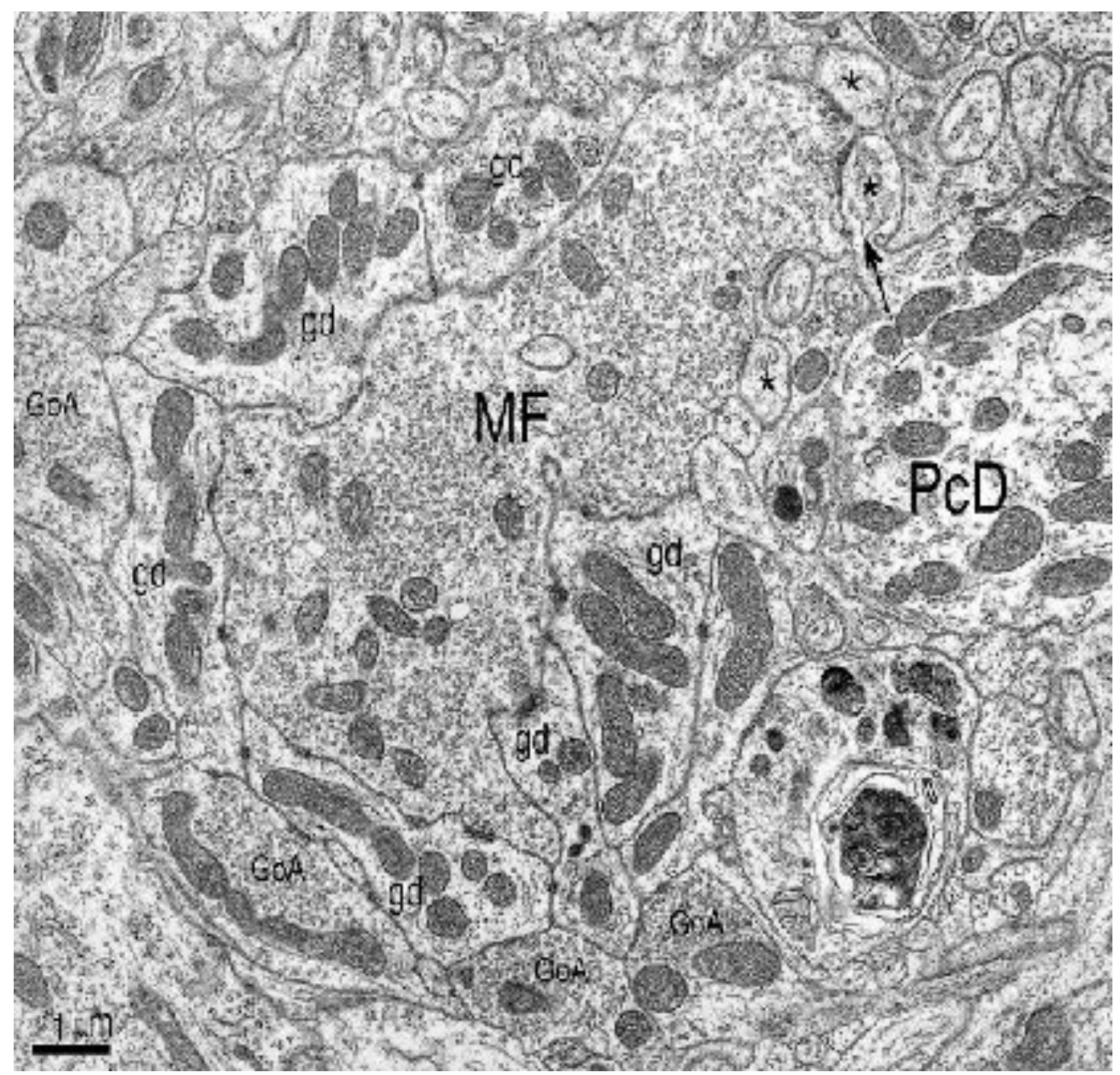

